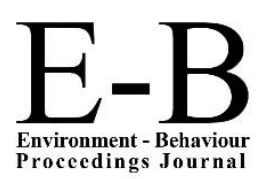

\title{
AicE-Bs2015Barcelona
}

$6{ }^{\text {th }}$ Asia-Pacific International Conference on Environment-Behaviour Studies,

Barcelona School of Architecture (ETSAB), Barcelona, Spain,31 Aug.- 05 Sep. 2015

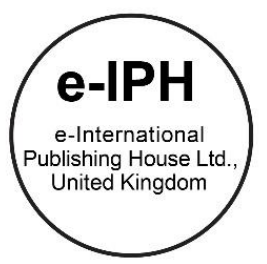

\section{Creating a Culture of Sustainability using Mission Statements of Cooperative Organizations}

\author{
Nooraslinda Abdul Aris ${ }^{*}$, Rohana Othman ${ }^{2}$, Wan Mohd Yusof Wan Chik 3 , Safawi Abdul Rahman ${ }^{4}$ \\ ${ }^{1}$ Faculty of Accountancy, Universiti Teknologi MARA, 40450 Shah Alam, Selangor, Malaysia \\ ${ }_{2}^{2}$ Accounting Research Institute, Universiti Teknologi MARA, 40450 Shah Alam, Selangor, Malaysia \\ ${ }^{3}$ Faculty of Contemporary Islamic Studies, Sultan Zainal Abidin University, 21300 Kuala Terengganu, Terengganu, Malaysia \\ ${ }^{4}$ Faculty of Information Management, Universiti Teknologi MARA, 40150 Puncak Perdana, Selangor, Malaysia
}

\begin{abstract}
Mission statements are recognized as effective strategic management tools that influence firms' performance. The evolution of a culture of sustainability begins with a mission statement that strikes a balance between financial performance and social commitments. The clear articulation of sustainability as part of the firm's mission, values, goals, and strategy are key factors in fostering sustainability focused culture. This study illustrates the fundamental tenets of the culture of organizational sustainability model proposed by Galpin, Whitttington, and Bell (2015) using selected cooperatives in Malaysia. The contents of the mission statements were then analyze using the nine elements model by Pearce and David (1987) in findings its relations to and the existence of sustainability culture within the cooperatives. Findings from the study confirm building an organizational infrastructure that fosters a culture of sustainability results in positive employee and organizational-level sustainability performance. A reference was made to Bank Rakyat, one of the leading cooperative-based banking in the country for its outstanding performance.
\end{abstract}

(C) 2016. The Authors. Published for AMER ABRA by e-International Publishing House, Ltd., UK. Peer-review under responsibility of AMER (Association of Malaysian Environment-Behaviour Researchers), ABRA (Association of Behavioural Researchers on Asians) and cE-Bs (Centre for Environment-Behaviour Studies, Faculty of Architecture, Planning \& Surveying, Universiti Teknologi MARA, Malaysia.

Keywords: Mission statement; sustainability; culture; cooperative

\section{Introduction}

Firms today need systemic approaches to sustainability if they are to be competitive over the long-term. The phrases sustainability, corporate social responsibility, corporate social performance, going green and the "triple bottom line" (Elkington, 1998) all refer to organizations enhancing their long-term economic, social and environmental performance. There is an everexpanding volume of literature underscoring the importance of sustainability to organizations and its positive impact on performance. A formal mechanism to communicate the organization's policies, procedures, plans and strategies (Rajasekar, 2013) must be established and put in place covering both internal and external stakeholders. This is usually known as a mission

\footnotetext{
${ }^{*}$ Corresponding author. Tel.: +0-000-000-0000

E-mail address: nooraslinda@salam.uitm.edu.my
}

(C) 2016. The Authors. Published for AMER ABRA by e-International Publishing House, Ltd., UK. Peer-review under responsibility of AMER (Association of Malaysian Environment-Behaviour Researchers), ABRA (Association of Behavioural Researchers on Asians) and cE-Bs (Centre for EnvironmentBehaviour Studies, Faculty of Architecture, Planning \& Surveying, Universiti Teknologi MARA, Malaysia. 
statement. As effective strategic management tools, mission statements influence not only performance but also assist organizations in developing their long-term plans as well as managing their day-to-day operations (Rajasekar, 2013). By defining a mission, an organization is making a statement of its purpose, a unique set of ideas that is realistic and economically feasible. Thus, a mission statement is widely assumed to facilitate coherence within the organization by providing direction and purpose; serving as a control mechanism; constituting a guide for organizational decision-making; and giving a meaning to work that inspires and motivates organization members (Bartkus \& Glassman, 2008). A well-established and documented mission statement will allow organization to continuously scan their internal and external environment and take necessary action to maintain their sustainability; hence enabling response to changing environmental, market conditions, technologies advancement, and emerging opportunities and to evade risk and threats.

Cooperatives are also known as social enterprises (SE) that operates businesses both to raise revenue and to further enhance the social missions of their organisations (Zainon et al., 2014) that include members, society and the environment. As an enterprise that strives for the betterment of the economy, society, and its members, this objective could be used in defining the appropriate vision and mission. Decision-making in cooperatives follows the one-member-one-vote principle, thus distinguishing them from enterprises with control rights that are proportionate to equity. Both the system of voluntary and open membership and the considerable co-determination rights for members make cooperatives particularly compatible with the societal expectations of multi-dimensional sustainability goals. The dynamic development of cooperatives clearly requires an educated and skilled board of directors drawn from an educated and involved membership to be competitive.

Organizational culture is defined as a set of beliefs, values, and assumptions that are shared and influence the behavior of organizational members (Schein, 2004). Creating a culture of sustainability requires a multi-level approach and ideally begins with the top management team. These efforts must be complemented by operational practices that permeate the entire organization. For example, an organization's mission, values, goals, and strategy can help send signals to internal and external stakeholders about the focus and direction of the firm. Similarly, the criteria used for hiring and promotion can also convey to employees the types of activities that will be rewarded. Finally, the content and modes of communications, workforce training, and the performance management processes all support the strategic initiative of creating a culture of sustainability. Without a diligent effort to create an organizational infrastructure that supports the development of a sustainability strategy, the firm's efforts to successfully implement a sustainability strategy will be severely hindered.

This study aims to exemplify the key tenets of the culture of sustainability model proposed by Galpin et al., (2015) using selected cooperatives in Malaysia. The selection is based on the ranking drafted by the Malaysian Co-operative Societies Commission (MCSC) and information available via the internet. The contents priorities of the mission statements were then analyze using the nine elements model by Pearce and David (1987) in findings its relations to and the existence of sustainability culture within the cooperatives.

The rest of the sections are ordered as follows: a review of the extant literature on the culture of sustainability and mission statements; followed by a brief description of the methodology used to collect and analyze the data. The findings are then discussed in detail, and the study implications are addressed after that. The last section concludes and offers recommendations for the cooperative sector.

\section{Literature Review}

\subsection{Sustainable Development and Sustainability}

Sustainable development has emerged as a concept that combines the need for meeting the current requisites without compromising the future generation needs (United Nations, 1987). It is now regarded as a dynamic process and an end goal for most organizations (Raissa, Setiawan, \& Rahmawati, 2014). The concept centers on a balance between society, economy and the environment for current and future health. Although the definition of sustainable development remains vague, the concept remains highly appreciated, demanded and engaged in science as well as in praxis as it covers vast variation of values, objectives and social levels (Pitrènaitè-Žilèniené \& Mikulskienè, 2014). It has been recognized that economic growth alone is not enough: the economic, social and environmental aspects of any actions are interconnected (Bekmezci, 2015).

Concerns about sustainability or the "triple bottom line", the three dimensions of performance: economy, social and the environment has gained attention among the companies since the declaration made by the United Nations in 1987. The concept 
of sustainability has bloomed as a prerequisite for strategies of companies, nations, and international structures (PitrènaitèŽilènienė \& Mikulskienè, 2014). Researchers has tried to adapt sustainability in areas such as reporting, product development, strategy, innovation, technology and corporate governance in various industries (Bekmezci, 2015; Erdoğan \& Durmaz, 2014; Kuzu, Gökbel, \& Güleş, 2013; Raissa et al., 2014; Speziale \& Klovien, 2014). Sustainability seems to be crucial in ensuring the longevity of the business and gaining competitive advantage.

Sustainability for cooperatives is vital a resource for managing change towards a sustainable global economy that combines long-term profitability with ethical behavior, social justice, and environmental care. Empirical testing of the three elements of sustainability in the cooperatives context would be beneficial in ensuring its contribution to nation building. As a social enterprise, the sustainability of cooperatives is an especially credible pursuit as it makes sense from an economic point of view and focuses on the company's core processes. Thus, creating a right culture is vital alongside product development, quality services, resource efficiency, and while environment protection must also be promoted. By doing so, it is hoped that the cooperative sector could create a distinct profile in the market arena.

\subsection{Culture of Sustainability Model}

This model integrates multiple organizational processes that are built upon a comprehensive perspective that seeks to underscore the importance to managers that efforts to create a culture of sustainability are just as critical. The process of fostering a culture of sustainability is being seen as a series of linear steps. In reality, the process is iterative. Each section of the model should be revisited and revised as necessary to support the evolution of a firm's sustainability efforts. This study focuses only on the first crucial process in the development of mission, values, goals and strategy that usually transform into the culture of an organization.

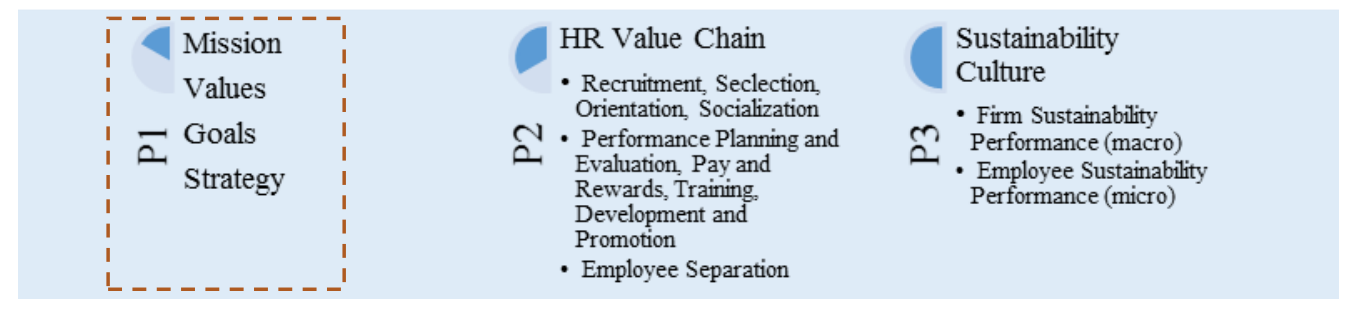

Fig. 1. Culture of Sustainability Model (adopted from Galpin et al., 2015)

\subsection{Mission Statements}

Mission statements refer to an organization's raison d'être, including central tasks and duties. In general it consists of three meta-components: a vision and a statement of goals; a statement of mission and a self-definition; and an organization's philosophy and values (Baetz \& Bart, 1996; David, 1989; Ireland \& Hirc, 1992). The vision component of mission statements describes a long-term, future-oriented, and comprehensive view of an organization's development. These tasks may be related to the organization's customers (e.g., offering high-level services) or its members (e.g., ensuring job security) or the society in general (e.g., facilitating political education). The philosophy and values provide guiding attitudes, behavior, and decision-making in the organization.

\subsection{Setting Culture of Sustainability Using Mission Statements}

A mission statement is e a powerful tool for setting the strategic direction and tactical actions of the company as it recognizes how a firm defines itself and establishes the priorities of the organization (Azizi \& Makizadeh, 2014). A well-designed mission statement describes the company's primary, distinctive purpose and can help set a firm apart from other similar organizations. Considerable research has shown that a well-articulated mission statement provides critical signals to stakeholders regarding the 
aims of the organization and can ultimately lead to positive outcomes that benefit the entire firm (Desmidt, Prinzie, \& Decramer, 2011; Donker, Poff, \& Zahir, 2007).

Developing an organizational culture of sustainability begins with a mission statement that strikes a balance between financial and social performance, yet seeks to achieve high performance in terms of both of these areas. Mission statements that adopt this balanced posture will convey to both internal and external stakeholders that the firm does not consider success in financial and environmental terms to be mutually exclusive. Instead, managers will lead the organization in a way that reflects success in both financial and societal terms.

\section{Methodology}

This study employs a qualitative approach. Information available on the internet (websites, blog, and Facebook) is the core instrument used for data collection in this study. The concepts such as "mission", "vision", "aim", "objectives", "philosophy", and "values" were mostly used interchangeably (Bart, 1998; Pearce \& David, 1987). For this reason, should the mission or vision not be found; pertinent information on the other headings mentioned above was sought instead. Using content analysis, the available information was used to deduce the Malaysian cooperatives statements in terms of content priorities and its ability in sustaining its position over the years.

The contents of such statements were reviewed and ranked using Pearce and David (1987) nine elements model. Three scores were independently employed to record the overall score of components in each function. A value of 0 means the statement does not include the component, 1 means the statement contains the component in vague terms, and 2 means the component is clearly expressed in the statement text. The weighted average score was used to compare the mission statements of various cooperatives function.

\subsection{Sample Population}

A total of 152 cooperatives were selected based on the ranking made by the MCSC from years 2011 to 2014 . This yearly ranking was made based on 70\% financial and 30\% non-financial weight that were introduced in 2008. The year 2008 to 2010 was excluded from the analysis as $26 \%$ of the cooperatives appeared only once in the ranking. This resulted in 152 cooperatives being selected as a population sample. From this sample, only $55 \%$ of the cooperatives were accessible via the internet that clearly displayed their mission, vision, strategy and activities of the cooperatives. The remaining was not available via the Internet probably because they may have opted for the traditional way of documenting and communicating the company's activities through a face-to-face meeting or via letter. The final sample of the population is presented in Table 1 below:

Table 1. Population and Final Sample of Cooperatives by Function

\begin{tabular}{lll}
\hline Top 100 cooperatives year 2011-2014 & \\
\hline & $\mathrm{N}$ & $\%$ \\
Accessible via internet & 83 & $55 \%$ \\
No access via internet & 69 & $45 \%$ \\
\hline & 152 & $100 \%$ \\
\hline
\end{tabular}

\begin{tabular}{lll}
\hline Cooperative by Function & $\mathbf{N}$ & $\%$ \\
\hline Banking & 2 & $2 \%$ \\
Housing/Construction & 4 & $5 \%$ \\
Service & 6 & $7 \%$ \\
Transportation & 6 & $7 \%$ \\
Agriculture & 9 & $11 \%$ \\
Consumer & 14 & $17 \%$ \\
Credit & 42 & $51 \%$ \\
\hline Final sample & $\mathbf{8 3}$ & $\mathbf{1 0 0 \%}$ \\
\hline
\end{tabular}




\section{Findings and Analysis}

\subsection{Sustainability element in Cooperative Mission Statements}

Mission statements are the first step in the process of creating a corporate identity (Goodman, 1994). The future vision includes the expression of the commitment to survival, growth and profitability (Pearce \& David, 1987). Today's challenging environment has forced organizations to scale up their businesses for sustainability reasons that are future oriented. This item is vital in ensuring the longevity of any businesses including the cooperatives. As an engine of economic growth, the cooperative sector need not only be profitable but also survive and sustain for the benefit of members and society.

\subsection{Content Priorities of Cooperatives Mission Statements}

The contents of the mission statements are classified into two categories - external and internal. The classification allows the stakeholders to assess the priorities among the cooperatives. Prior studies suggested that mission statement contents of nonprofit organizations do not relate consistently to performance (Kirk \& Nolan, 2010). This in fact is contrary to profit-oriented organizations whereby the mission statement contents relates positively to company's performance (Bartkus \& Glassman, 2008; Blair-Loy, Wharton, \& Goodstein, 2011). The mission statement of profit-oriented organizations is important as it refers to the company philosophy and values, purpose and self-concept, and commitment to individual interest groups. Comprehensive as well as relatively short mission statements relate positively to mission statement's effectiveness (Braun, Wesche, Frey, Weisweiler, \& Peus, 2012).

Table 2. Content priorities among the cooperatives in Malaysia

\begin{tabular}{|c|c|c|c|c|c|c|c|c|}
\hline & 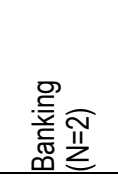 & 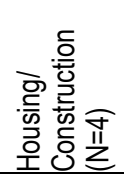 & 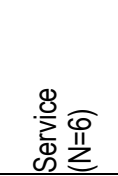 & 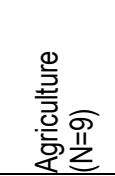 & 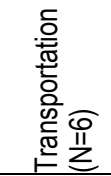 & 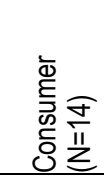 & 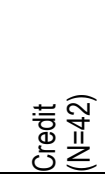 & $\begin{array}{l}\text { Average } \\
\text { Score }\end{array}$ \\
\hline Customer & 1.500 & 1.750 & 1.833 & 1.444 & 1.667 & 1.500 & 1.667 & 1.623 \\
\hline Public Image & 2.000 & 1.500 & 1.667 & 1.333 & 1.167 & 1.214 & 1.000 & 1.412 \\
\hline Geographic Market & 1.500 & 1.750 & 1.500 & 1.556 & 1.500 & 0.929 & 0.595 & 1.333 \\
\hline Total External & 5.000 & 5.000 & 5.000 & 4.333 & 4.333 & 3.643 & 3.262 & 4.367 \\
\hline Product/ Service & 2.000 & 2.000 & 1.500 & 1.556 & 1.500 & 1.429 & 1.262 & 1.607 \\
\hline Technology & 2.000 & 1.500 & 1.667 & 1.556 & 1.333 & 1.500 & 1.262 & 1.545 \\
\hline Philosophy & 2.000 & 1.250 & 1.667 & 1.222 & 1.167 & 1.071 & 1.262 & 1.377 \\
\hline Distinctive Competence & 2.000 & 1.500 & 1.500 & 1.333 & 1.333 & 0.714 & 0.786 & 1.310 \\
\hline Future vision & 1.000 & 0.500 & 0.833 & 1.333 & 0.667 & 0.357 & 0.405 & 0.728 \\
\hline Employees & - & 0.750 & 0.500 & 0.333 & 0.833 & 0.643 & 0.524 & 0.512 \\
\hline Total Internal & 9.000 & 7.500 & 7.667 & 7.333 & 6.833 & 5.714 & 5.500 & 7.078 \\
\hline Average/function & 14.0000 & 12.5000 & 12.6667 & 11.6667 & 11.1667 & 9.3571 & 8.7619 & \\
\hline
\end{tabular}

The overall results show that cooperative banking scores the highest as they explicitly included the public image, product/service, technology, philosophy and competencies in their statements. Employees who are an important component, however, does not appear in these statements but was included in their business pillars. The future vision that is a concern for 
growth and survival which involves the need to sustain was observed among the lower scores. Services, housing/construction, agriculture and transportation scores are within the acceptable range. Consumer cooperatives found to score the second least seem to focus on customer, product/service and technology. Credit-based cooperatives in the sample scored the lowest with the focus mostly on the customer. The product/service, technology and philosophy were ranks as their secondary priorities.

Individually, customer, product/services, and technology are the three top priorities of the cooperatives in Malaysia. This is followed by the public image, philosophy, geographic market and distinctive competence. Future vision and employees are two factors that seem to be less important as it was not mentioned in the statements. Prior studies reported that organizations having values such as cohesiveness, empowerment, and participatory decision-making are likely to create an environment that fosters employee satisfaction. Satisfied employees were found to relate positively to organizational performance (Ryan, Schmit, \& Johnson, 1996; Schneider, Hanges, Smith, \& Salvaggio, 2003) and even customer satisfaction (Harter, Schmidt, \& Hayes, 2002). Thus, the employee is one of the top priorities that cooperative should take into consideration if the statements were to be reviewed.

\section{Discussion and Conclusion}

This study intended to show cooperatives' priorities in meeting its stakeholders need to sustain in today's competitive market. Malaysian cooperatives, in general, are likely to focus on the customer who is usually the cooperative members and the products and services being offered. Findings revealed similar results as Azizi and Makizadeh (2014) that Malaysian cooperatives paid less attention to other elements such as geographic market, distinctive competence, future vision and employees.

Regarded as indicators of corporate identity, mission statements provide the grounds for positive corporate image and help the organization in its first step towards gaining a positive reputation in the eyes of key stakeholders. As a strategic management tool, mission statements can be used in cultivating the culture of sustainability. It is important that the mission statement conveys the role of the cooperative in the marketplace, as well as in the society.

The cooperative sector in Malaysia has been entrenched towards contributing to the national growth as a tool for enhancing the standards of living of their members, particularly the low-income earners as well as the society as a whole. A balance in the triple bottom line of economic, social and environmental aspects when maintained by cooperatives helps them sustain competitiveness even when there are market disruptions or industrial disturbances. This reflects that concern on sustainability can lead towards growth, profitability, positioning, consistency and longevity.

Cooperatives can successfully integrate sustainability concerns into strategic and operational decision-making processes while concurrently meeting its traditional business goals. This could be done by reviewing and changing the existing mission statements to include the necessary culture of sustainability. Indeed, if a cooperative decides to amend its mission to symbolize becoming more sustainable without subsequent efforts that are substantive in nature, they run the risk of being accused of "green washing" or superficially using sustainability merely as a marketing tactic. Hence, to cultivate a culture of sustainability, the cooperative should begin with their mission statements, and then proceed with installing sustainability in their formal and informal value systems.

To illustrate this point, Bank Rakyat is one of the successful cooperative-based banking organizations in Malaysia which has successfully built and fostered a culture of sustainability that resulted in positive employee and organizational-level sustainability performance. The Banker recognized Bank Rakyat as the eleven top Islamic financial institutions with a total asset of RM82.88 billion and profit before tax and zakat of RM2.13 billion with a total of 4,695 employees in 2013. The employees retention has been very high (lower employee turnover) as the employees are motivated to assist the company in achieving the stated objectives. The return to the depositors and members has been higher compared to commercial banks and other cooperatives in the country. Bank Rakyat's outstanding performance has made it one of the exemplary cooperatives in Malaysia, gaining recognition worldwide.

Further consideration of readability, quality and effectiveness of the statements will provide evidence on its understandability and performance via brand or reputation. Once the contents are prioritized, it is equally crucial that a mission statement be understood as this will translate into forming the culture desired by the management. Cultures of sustainability signal the readiness of the management to commit to transparency, mutual respect and fairness to the cooperatives' stakeholders. 


\section{Acknowledgements}

The authors wish to express their gratitude to University Teknologi MARA (UiTM) for funding the research project and the administrative support.

\section{References}

Azizi, S., \& Makizadeh, V. (2014). Strategic priorities of Iranian companies : an application of mission statement content analysis. Management \& Marketing, 9(4), $471-482$.

Baetz, M. C., \& Bart, C. K. (1996). Developing mission statements which work. Long Range Planning, 29(4), 526-533. doi:10.1016/0024-6301(96)00044-1

Bart, C. K. (1998). The Relationship Between Mission Statements and Firm Performance: An Exploratory Study. Journal of Management Studies, 35(6), 823853. doi:10.1111/1467-6486.00121

Bartkus, B. R., \& Glassman, M. (2008). Do firms practice what they preach? The relationship between mission statements and stakeholder management. Journal of Business Ethics, 83(2), 207-216. doi:10.1007/s10551-007-9612-0

Bekmezci, M. (2015). Companies' Profitable Way of Fulfilling Duties towards Humanity and Environment by Sustainable Innovation. In Procedia - Social and Behavioral Sciences (Vol. 181, pp. 228-240). Elsevier B.V. doi:10.1016/j.sbspro.2015.04.884

Blair-Loy, M., Wharton, a. S., \& Goodstein, J. (2011). Exploring the Relationship between Mission Statements and Work-Life Practices in Organizations. Organization Studies, 32(3), 427-450. doi:10.1177/0170840610397480

Braun, S., Wesche, J. S., Frey, D., Weisweiler, S., \& Peus, C. (2012). Effectiveness of mission statements in organizations - A review. Journal of Management and Organization, 18(4), 430-444. doi:10.5172/jmo.2012.18.4.430

David, F. R. (1989). How companies define their mission. Long Range Planning, 22(1), 90-97. doi:10.1016/0024-6301(89)90055-1

Desmidt, S., Prinzie, A., \& Decramer, A. (2011). Looking for the value of mission statements: a meta-analysis of 20 years of research. Management Decision, 49(3), 468 - 483. doi:10.1108/00251741111120806

Donker, H., Poff, D., \& Zahir, S. (2007). Corporate Values, Codes of Ethics, and Firm Performance: A Look at the Canadian Context. Journal of Business Ethics, 82(3), 527-537. doi:10.1007/s10551-007-9579-x

Elkington, J. (1998). ACCOUNTING FOR THE TRIPLE BOTTOM LINE. Measuring Business Excellence. doi:10.1108/eb025539

Erdoğan, D., \& Durmaz, V. (2014). Adopting Mission and Vision Statements by Employees: The Case of TAV Airports. In Procedia - Social and Behavioral Sciences (Vol. 150, pp. 251-262). Elsevier. doi:10.1016/j.sbspro.2014.09.051

Galpin, T., Whitttington, J. L., \& Bell, G. (2015). Is your sustainability strategy sustainable? Creating a culture of sustainability. Corporate Governance: The International Journal of Business in Society, 15(1), 1-17. doi:10.1108/CG-01-2013-0004

Goodman, M. B. (1994). Corporate Communication: Theory and Practice. (M. B. Goodman, Ed.). State University of New York Press.

Harter, J. K., Schmidt, F. L., \& Hayes, T. L. (2002). Business-unit-level relationship between employee satisfaction, employee engagement, and business outcomes: A meta-analysis. Journal of Applied Psychology, 87(2), 268-279. doi:10.1037/0021-9010.87.2.268

Ireland, R. D., \& Hirc, M. A. (1992). Mission statements: Importance, challenge, and recommendations for development. Business Horizons, 35(3), 34-42. doi:10.1016/0007-6813(92)90067-J

Kirk, G., \& Nolan, S. B. (2010). Nonprofit mission statement focus and financial performance. Nonprofit Management and Leadership, 20(4), $473-490$. doi:10.1002/nml.20006

Kuzu, Ö. H., Gökbel, H., \& Güleş, H. K. (2013). Developing Sustainable Relations with Internal and External Stakeholders in Universities: Vision And Mission Views. Procedia - Social and Behavioral Sciences, 103, 281-289. doi:10.1016/j.sbspro.2013.10.336

Pearce, J. A. I., \& David, F. (1987). Corporate Mission Statements: The Bottom Line. The Academy of Management Executive, 1(2), $109-115$.

Pitrènaitè-Žilènienè, B., \& Mikulskienè, B. (2014). Bridging political , managerial and legislative components of sustainability strategy with business demands. In Procedia - Social and Behavioral Sciences (Vol. 150, pp. 950-957). Elsevier. doi:10.1016/j.sbspro.2014.09.107

Raissa, D. R., Setiawan, R. P., \& Rahmawati, D. (2014). Identification of Indicators Influencing Sustainability of Minapolitan Area in Lamongan Regency. Procedia - Social and Behavioral Sciences, 135, 167-171. doi:10.1016/j.sbspro.2014.07.342

Rajasekar, J. (2013). A Comparative Analysis of Mission Statement Content and Readability. Journal of Management Policy \& Practice, 14(6), 131-148.

Ryan, A. M., Schmit, M. J., \& Johnson, R. (1996). Attitudes and Effectiveness: Examining Relations at an Organizational Level. Personnel Psychology, 49(4), 853-882. doi:10.1111/j.1744-6570.1996.tb02452.x

Schein, E. H. (2004). Organizational Culture and Leadership (3rd Editio.). San Francisco: Jossey-Bass. doi:10.1080/09595230802089917

Schneider, B., Hanges, P. J., Smith, D. B., \& Salvaggio, A. N. (2003). Which comes first: Employee attitudes or organizational financial and market performance? The Journal of Applied Psychology, 88(5), 836-851. doi:10.1037/0021-9010.88.5.836

Speziale, M., \& Klovien, L. (2014). The relationship between performance measurement and sustainability reporting : A literature review. In Procedia - Social and Behavioral Sciences (Vol. 156, pp. 633-638). Latvia: Elsevier. doi:10.1016/j.sbspro.2014.11.254

United Nations. (1987). Report of the World Commission on Environment and Development (Vol. 42/187). doi:10.1093/oxfordhb/9780199560103.003.0005

Zainon, S., Ahmad, S. A., Atan, R., Wah, Y. B., Bakar, Z. A., \& Sarman, S. R. (2014). Legitimacy and Sustainability of Social Enterprise: Governance and Accountabilit 